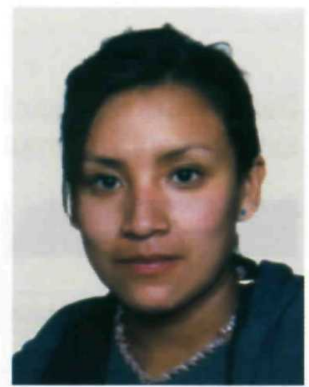

Diana Alejandra Saetama G.

esde tiempos inmemoriales las diferentes culturas han manejado y usado las plantas, animales y otros microorganismos para la obtención de productos alimenticios, medicinales y de otros usos. Este proceso ha sido posible gracias a los conocimientos obtenidos de generación en generación.

La ciencia moderna resta importancia a los procedimientos tecnológicos tradicionales, a pesar que muchos de ellos fueron la base de la supervivencia de la humanidad. Para tener una idea elemental de las investigaciones biotecnológicas contemporáneas definiremos algunos conceptos:

La Biotecnología es el conjunto de técnicas y procedimientos, que involucran el uso, transformación y modificación de organismo vivos, para obtener productos de interés comercial aplicados a la agricultura y otros sectores productivos.

¿Qué es lo que se manipula en los seres vivos? Los seres vivios están constituidos por células, que en cu conjunto constituye el organismo de cada individuo. Cada especie tienen en su célula un determinado número de cromosomas, los cuales están constituidos por cadenas de proteínas que forman el ADN (Acido Dixosirribonucleico), que en su interior contienen los genes, estas estructuras codifican y determinan las características principales de cada individuo que son transmitidos de padres a hijos.

La Genética convencional nos

\section{Los cultivos Transgénicos en el Nuevo Milenio}

indica que los genes presentan los siguientes caracteres: no están influenciados por el ambiente externo, los genes son estables y no cambian, mientras que los Nuevos descubrimientos manifiestan que los genes funcionan en redes complejas, en forma lineal, multidimensional y circular, los genes están sujetos a la regulación del ambiente, son dinámicos y fluidos y pueden cambiar en respuesta al medio ambiente, los genes pueden saltar horizontalmente entre especies no relacionadas y combinarse.

Es decir que los genes responsables de una determinada característica (tolerancia a herbicidas, resistencia a plagas y enfermedad, etc) son obtenidos a partir de especies genéticamente relacionadas a los cultivos o a través de las hibridaciones, sin embargo las técnicas de recombinación genética permite aislar los genes de una especie y transferirlo a otra, aún cuando estas especies no estén genéticamente relacionadas.

Por ejemplo: genes de pollo y del gusano de seda, han sido introducidos en variedades de papas, logrando así resistencia a enfermedades bacterianas, en la ganadería se introdujo la hormona de crecimiento bovino para aumentar la producción lechera, y así una serie de organismos transgénicos ya creados y que por falta de información no sabemos que existen.

Cabe destacar, que la agricultura transgénica puede desencadenar una serie de impactos desfavorables al ecosistema; primero, los cultivos transgénicos podrían convertirse en malezas difíciles de erradicar; segundo, al existir un intercambio de genes se puede dotar a una planta de ventajas significativas para su sobrevivencia en los campos cultivados o naturales alterando el ambiente; tercero la resistencia a ciertos herbicidas puede generar dependencia de herbicidas tóxicos, finalmente los cultivos con resistencia a plagas y enfermedades producen toxinas que afectan a enemigos naturales o esparcirse en la cadena de alimentos.

Pero si bien se han realizado muchos experimentos para evaluar los riesgos de estos cultivos, es evidente la necesidad de exhaustivos estudios a fin de determinar las consecuencias en el ecosistema, así como establecer las estrategias apropiadas para su manejo. 